TAPROBANICA, ISSN 1800-427X. June, 2014. Vol. 06, No. 01: pp. 63-65.

(C) Research Center for Climate Change, University of Indonesia, Depok, Indonesia

\& Taprobanica Private Limited, Homagama, Sri Lanka

http://www.sljol.info/index.php/tapro

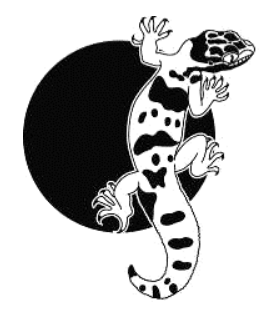

\section{The highest elevation record of the brown long-eared bat (Plecotus auritus)}

B. H. Hodgson collected the holotype in 1847, named it Plecotus homochrous, and labelled the animal as a male taken in the 'central region of sub-Himalayas' (Horsfield, 1855; Spitzenberger et al., 2006) which does not necessarily mean Nepal and, in fact, may have been Darjeeling in India or Sikkim (Sanborn, 1950; Bates \& Harrison, 1997). Fleming collected a specimen (Sanborn, 1950), most certainly from Nepal, which Sanborn labelled Plecotus homochrous. This specimen is retained in the collections of the Field Museum of Natural History (FMNH), Chicago, USA where its identity is listed currently as $P$. auritus homochrous (Pearch, 2011) based on the taxonomy of Csorba et al. (1999). Due to ambiguity of Hodgson's record we are treating Fleming's specimen as the first from Nepal. Bates \& Harrison (1997) refers to the species as $P$. auritus. The genus Plecotus includes a number of cryptic forms and further investigation may well prove that even Plecotus auritus is comprised of more than one taxon (Spitzenberger et al., 2006).

This species is distributed throughout the southern slopes of the Himalayas. The westernmost record is from Murree, Punjab, Pakistan, at an elevation $2500 \mathrm{~m}$ in the southern slopes of the Pir Panjal mountain chain. There is also a record from Pokhra, in Uttaranchal, India, at an altitude $2000-3000 \mathrm{~m}$ a.s.l. according to the map [note on label says $10700 \mathrm{ft} .(=3300 \mathrm{~m})]$. These localities are all in oak-conifer mixed forest. The altitude of the Nepalese locality of Fleming (Kali Gandak River at Jomson) is 9200 $\mathrm{ft}(=2800 \mathrm{~m})$ a.s.l. The easternmost locality is probably Darjeeling (Jerdon, 1867) in north-east India, West Bengal state at an altitude of about 2000m a.s.l (Spitzenberger et al., 2006).
A dead adult female of this species was found near the base of a cliff along the trail on the way to Thinkar village, near the irrigation canal and close to Thinkar Stream (Khola), Chhonhup V. D. C., Mustang District, Nepal (29 $12^{\prime}$ '01.97'N; 83 56'34.37'E; 3938m a.s.1.) in June, 2003. The naturally well-preserved specimen (whole body with skull) was retained dry. It was collected by M. Chetri and transferred to the Natural History Museum, Swoyambhu, Kathmandu, Nepal (NHM 246) on 4 November 2003. Thirteen measurements (Table 1) were taken of the specimen using a steel scale. The area where the specimen was found is physiographically Tibetan Steppe in the Trans-Himalayan region of Nepal near the Nepal-Tibet border. The site is around $60 \mathrm{~km}$ north-east of Jomsom (about three days trekking) and about $15 \mathrm{~km}$ north of Lho Manthang. Vegetation of the area comprises of trees such as Populus sp. (Salicaceae) and Salix sp. (Salicaceae) while the shrubs are dominated by Caragana sp. (Fabaceae), and Rosa sp. (Rosaceae). Agricultural farming of oats, barley, radish, pea, and mustard are found in terraces. Near the site where the specimen was collected is an apple orchard. There are numerous natural caves (including some caused by wind erosion) and large man-made caves dug for shelter in the past. The temperature in the afternoon at the collection site was in the range of $15^{\circ}-20^{\circ} \mathrm{C}$.

The specimen has dorsal and ventral pelages that are uniformly dark brown, dense, and woolly. Hairs in the mid-dorsal region are $10.0-11.0 \mathrm{~mm}$ long and in the mid-ventral region $8.0 \mathrm{~mm}$. Dorsal fur extends to a very narrow area of the proximal part of the tail membrane. Hairs on the back, although appearing dark brown are, upon closer inspection, bi-coloured, with the basal zone, comprising less than half the hair length $(4.0 \mathrm{~mm})$, dark brown, with the tips lighter. The ventral hairs are also bi-coloured, the basal zone 
comprising more than half of the hair length blackish with the tips pale while, in the neck region, there is a yellowish tinge giving a grizzled appearance. Other than in the neck, ventral hairs have pale whitish tips which measure about $6.0 \mathrm{~mm}$ at the mid-ventral region. Ears, wing, and tail membranes are dark brown. The anterior margins and edges of ears have a lining of fine hairs. Toes are covered sparsely with brown hairs, their claws are short $(3 \mathrm{~mm})$, brown, and strongly curved.

Table 1: Morphometric measurements of the Plecotus auritus (NHM 246).

\begin{tabular}{lc}
\hline \multicolumn{1}{c}{ External Characters } & $\begin{array}{c}\text { Measurement } \\
(\mathbf{m m})\end{array}$ \\
\hline Forearm length & 41 \\
\hline Tibia length & 18 \\
\hline Hind foot length & 8 \\
\hline Tragus length & 15 \\
\hline th metacarpal length & 35 \\
\hline th metacarpal length & 36 \\
\hline 3rd metacarpal length & 36 \\
\hline Length of $1^{\text {st }}$ phalanx of $3^{\text {rd }}$ metacarpal & 16 \\
\hline Length of $2^{\text {nd }}$ phalanx of $3^{\text {rd }}$ metacarpal & 20 \\
\hline Length of $1^{\text {st }}$ phalanx of $4^{\text {th }}$ metacarpal & 11 \\
\hline Length of $2^{\text {nd }}$ phalanx of $4^{\text {th }}$ metacarpal & 12 \\
\hline Length of $1^{\text {st }}$ phalanx of $5^{\text {th }}$ metacarpal & 11 \\
\hline Length of $2^{\text {nd }}$ phalanx of $5^{\text {th }}$ metacarpal & 9 \\
\hline
\end{tabular}

The first Nepalese specimen, collected by Fleming, was supposedly from Jomsom $\left(28^{\circ} 49^{\prime} \mathrm{N}, 8^{\circ} 42^{\prime} \mathrm{E}\right)$ but, confusingly, the coordinates given in the FMNH catalogue of the collection locality are for Baglung and not Jomsom, The specimen was found frozen to a rock on a bank of the Kali Gandaki River, Mustang District at an elevation of $2804 \mathrm{~m}$ a.s.l. The vegetation of the area is subtropical evergreen deciduous or mixed forest.

MC's June 2003 specimen was the second collected in Nepal and, like Fleming's specimen, was collected in Mustang District. The find's location shows that the species can be found in the Tibetan sub-arid landscape. Sanborn (1950) provides the forearm length of the single female specimen collected at Jomson as $44.5 \mathrm{~mm}$, which is within the range of Indian examples of
Plecotus austriacus, the grey long-eared bat (41.9-45.1mm, $n=10$ ) but notably beyond the range of forearm measurements of $P$. auritus (36.5-40.3mm, $n=4$ ) (Bates \& Harrison, 1997) so we wonder about the identity of Fleming's specimen. Sanborn did not provide cranial measurements and he produces little other taxonomic evidence to confirm the specimen as P. auritus (Pearch, 2011). However, our specimen has measurements, including forearm dimensions that conform to those of $P$. auritus. The specimen was collected at an elevation of $3938 \mathrm{~m}$ a.s.1 and, with other known records along the Himalayas ranging from $2000-3300 \mathrm{~m}$ a.s.1., we can confidently say that the Chhonhup V.D.C. locality record is the highest altitude ever for P. auritus.
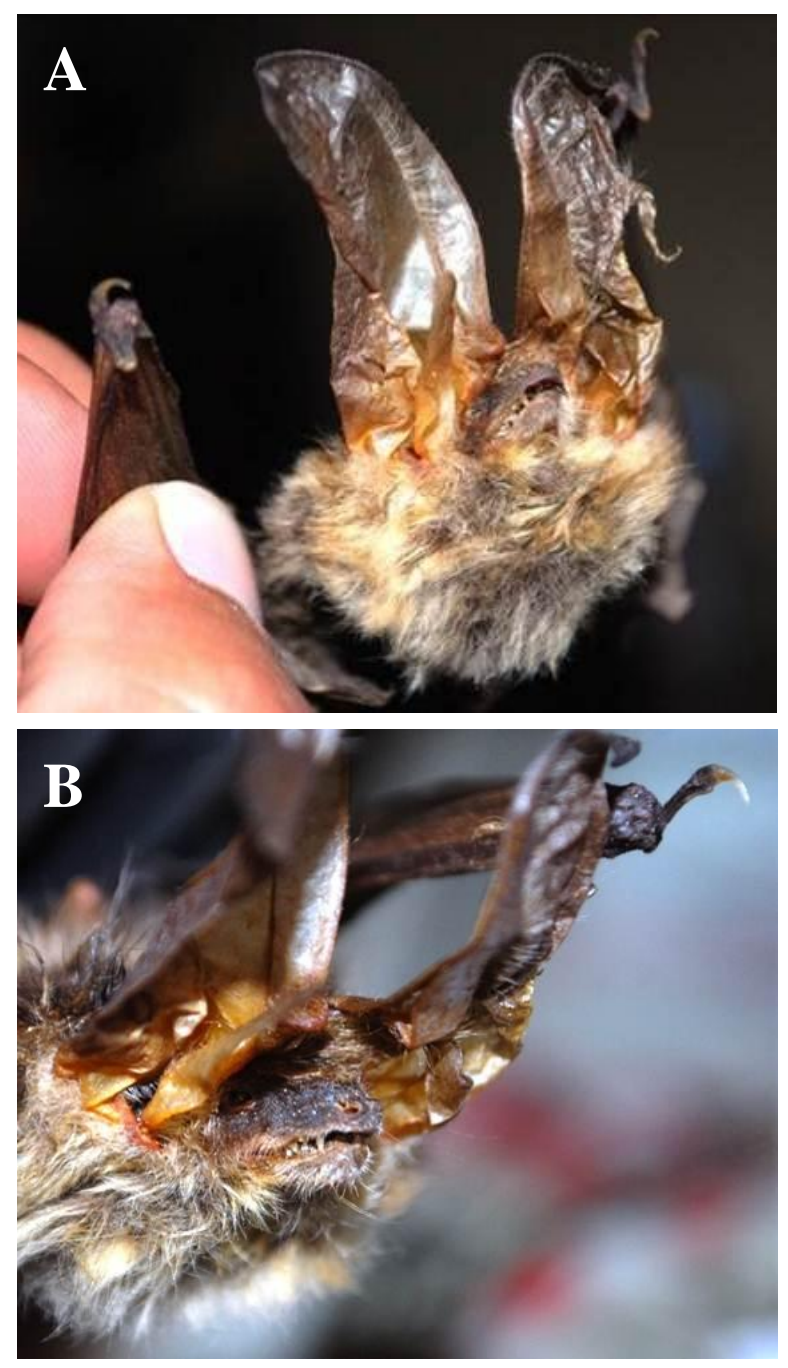

Figure 1: A, Frontal view; B, lateral view of face of specimen collected by M. Chetri (NHM 246). 


\section{Literatures cited}

Bates, P. J .J. and D. L. Harrison, 1997. Bats of the Indian Subcontinent. Harrison Zoological Museum Publication, United Kingdom: 258.

Csorba, G., S. V. Kruskop and A. V. Borissenko, 1999. Recent records of bats (Chiroptera) from Nepal, with remarks on their natural history. Mammalia, 63 (1): 61-78.

Hodgson, B. H., 1847. On a new species of Plecotus. Journal of Asiatic Society Bengal, 16: 894-896.

Horsfield, T., 1855. Brief notices of several new or little known species of Mammalia, lately discovered and collected in Nepal by Brian Houghton Hodgson. Annals and Magazine of Natural History series, 2 (16): 101-114.

Jerdon, T.C., 1867. The Mammals of India. Thomason College Press, Roorkee, India.

Pearch, M. J., 2011. A review of the biological diversity and distribution of small mammal taxa in the terrestrial ecoregions and protected areas of Nepal. Zootaxa, 3072: 286.

Sanborn, C. C., 1950. A Nepal record of the Longeared Bat (Plecotus homochrous Hodgson). Natural History Miscellanea, Chicago Academy of Sciences, 69:1-2.

Spitzenberger, F., P. P. Strelkov, H. Winkler, and E. Haring, 2006. A preliminary revision of the genus Plecotus (Chiroptera, Vespertilionidae) based on genetic and morphological results. Zoologica Scripta, 35: 187-230.

Submitted: 04 Jan. 2014, Accepted: 25 April 2014 Section Editor: Asoka Yapa

\section{S. Thapa ${ }^{1}$, K. B. Shah ${ }^{2} \&$ M. Chetri ${ }^{3}$}

${ }^{1}$ Small Mammals Conservation and Research Foundation, New Baneshwor, Kathmandu, Nepal; E-mail: sanjan@smcrf.org

${ }^{2}$ Natural History Museum, Tribhuvan University, Swoyambhu, Kathmandu, Nepal

${ }^{3}$ National Trust for Nature Conservation, Khumaltar, Lalitpur, Nepal 